\title{
Increasing Risk Over Time: Delayed Spleen Rupture After Trauma
}

\author{
Zamanla Artan Risk:Travma Sonrası Gecikmiş Dalak Rüptürü
}

Ulvi Mehmet Meral', Oğuz Hançerlioğulları' , Ahmet Turan llıca², Necati Salman³

${ }^{1}$ Clinic of General Surgery, Izmir Military Hospital, Izmir, Turkey

${ }^{2}$ Clinic of Radiology, Izmir Military Hospital, İzmir, Turkey

${ }^{3}$ Clinic of Emergency Medicine, Etimesgut Military Hospital, Ankara, Turkey

\section{ABSTRACT}

Introduction: Delayed rupture of the spleen is defined as splenic rupture occurring 48 hours or more after blunt abdominal trauma. The diagnostic process should involve the timely and proper use of focused assessment with sonography for trauma (FAST) and computerized tomography (CT).

Case Report: Our study hereby reports a case of a 21-year-old male patient who sustained a blunt abdominal trauma and who was subsequently discharged due to the observation of normal findings on the initial physical examination, ultrasonography, and CT. The patient was re-admitted to the hospital 15 days later with worsening complaints, after which he was diagnosed with splenic rupture and discharged from the hospital with full recovery after splenectomy.

Conclusion: The possibility of delayed splenic rupture should not be overlooked in blunt abdominal trauma patients with normal physical examination findings and a problem-free medical history. Although repeated physical examination and FAST are important diagnostic procedures, CT should be performed without delay in the presence of a high-energy trauma and hemodynamic instability.

Keywords: Delayed splenic rupture, blunt abdominal trauma, FAST Received: 16.07.2014 Accepted: 09.09.2014

\section{ÖZET}

Giriş: Künt batın travmasının 48 saat ve sonrasında gelişen dalak rüptürleri, gecikmiş dalak rüptürü olarak tanımlanır. Tanısal süreç, yerinde ve zamanında kullanılan focused assessment with sonography for trauma (FAST) ve bilgisayarlı tomografi (BT) tetkiklerini içermelidir.

Olgu Sunumu: Çalışmamızda künt batın travması ile başvuran; ilk başvurusunda muayenesi, ultrasonografi ve BT tetkikleri normal olarak değerlendirilip önerilerle taburcu edilen 21 yaşındaki erkek hastaya ait olgu sunulmaktadır. 15 gün sonra artan şikayetlerle hastaneye başvuran hastada dalak rüptürü tespit edilmiş, splenektomi sonrası şifa ile taburcu edilmiştir.

Sonuç: Fizik muayene bulguları ve tıbbi öyküsü normal olan künt batın travmalı hastalarda gecikmiş dalak rüptürü olasılığı göz ardı edilmemelidir. Tekrarlanan fizik muayene ve FAST önemli tanısal yöntemler olmakla birlikte yüksek enerjili travma ve hemodinamik instabilite bulunması durumunda BT gecikmeden uygulanmalıdır.

Anahtar Kelimeler: Gecikmiş dalak rüptürü; künt abdominal travma; FAST

Geliş Tarihi: 16.07.2014 Kabul Tarihi: 09.09.2014

\section{Introduction}

The spleen is the most commonly injured solid organ after blunt trauma to the abdomen (1). Delayed splenic rupture is defined as splenic rupture occurring 48 hours after trauma (2). Although it is reported that severe complications leading to death after severe abdominal trauma mostly occur 1 and 6 hours after trauma, there are reports on cases with splenic rupture occurring 70 days after trauma $(2,3)$. Delayed rupture of the spleen continues to have a significant mortality rate, despite the use of focused assessment with sonography for trauma (FAST) in the emergency room and improvements in conservative therapies in splenic injuries as an alternative to splenectomy. Our case is an event of splenic rupture that was diagnosed 15 days after sustaining multitrauma as a result of an assault.

This study was presented at $1^{\text {st }}$ National Gastrointestinal Surgery Congress, Turkish Republic of Northern Cyprus, 25-29 September 2013. 


\section{Case Report}

A 21-year-old male patient first presented to the primary care center after an assault, and then, he was referred to the emergency room of our secondary care hospital. The patient stated that he had complaints of headache and right flank pain. At the initial examination, he had edema in the left zygomatic area. His neurologic and abdominal examinations were normal. His vital signs were BP: 130/70 mm Hg, pulse rate: $85 / \mathrm{bpm}$ (regular), temperature: $36^{\circ} \mathrm{C}, \mathrm{SaO}_{2}: 99 \%$, and respiratory rate: $12 /$ per minute. His state of consciousness was normal (GCS: 15). However, the patient was further referred to a tertiary care unit due to the fact that the patient had multitrauma (abdominal, maxillofacial, and cranial), and computerized tomography (CT) was not available at our hospital. In the tertiary care unit, urinary tract ultrasonography and CT without contrast enhancement were performed due to complaints of right flank pain, and neither of them revealed any significant pathology (Fig. 1). After a clinical and radiologic assessment, the patient discharged from the hospital with a recommendation of rest. Fifteen days after the trauma, the patient was admitted to our emergency room for the second time due to abdominal pain and gradually increasing weakness that began in the morning hours. The patient's systemic blood pressure was $80 / 45 \mathrm{~mm} \mathrm{Hg}$, and the pulse rate was 110/bpm on admission. At the abdominal examination, we detected widespread pain and tenderness. The patient did not have any history of secondary trauma since the first admission. A hemogram was obtained, and emergent abdominal ultrasonography revealed intra-abdominal free fluid collection, capsular rupture in the superior half of the spleen, and a $5 \times 5-\mathrm{cm}$ laceration, after which the patient underwent an emergency operation. In the meantime, hemoglobin was 7.7 $\mathrm{g} / \mathrm{dL}$, and hematocrit was 24\%. During an abdominal exploration, approximately 1000 cc of hemorrhagic fluid was aspirated from the abdominal cavity. The integrity of the splenic capsule was found to be disrupted on the diaphragmatic surface, and an approximately 5-cm splenic laceration was observed, with subcapsular hematoma (Fig. 2). The patient underwent a splenectomy, and he was discharged with full recovery after 8 days of hospitalization.

\section{Discussion}

A patient's developing splenic rupture secondary to blunt abdominal trauma may show hemodynamic instability and severe abdominal pain in the early period, but these patients may also show subtle symptoms and inconclusive physical examination findings (4). Our patient reported right flank pain and complaints predominantly related to other systems at the first admission. However, it is reported that minor trauma, including bending, twisting, and stretching the body, can produce splenic rupture in the late term in patients that are found to be normal in the initial evaluation after blunt abdominal trauma (5). The possibility of developing delayed splenic rupture with minor trauma after the initial blunt abdominal trauma indicates the importance of repeated physical examinations in the management of the cases, selection of the appropriate means of radiological imaging, and the need to restrict physical activity after discharge.

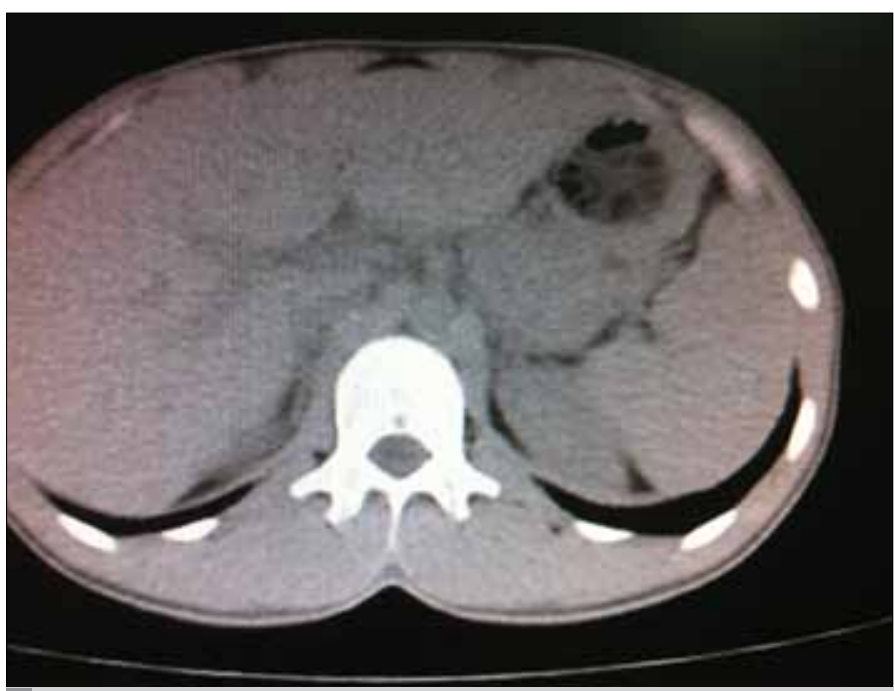

Figure 1. Abdominal CT image at the first admission

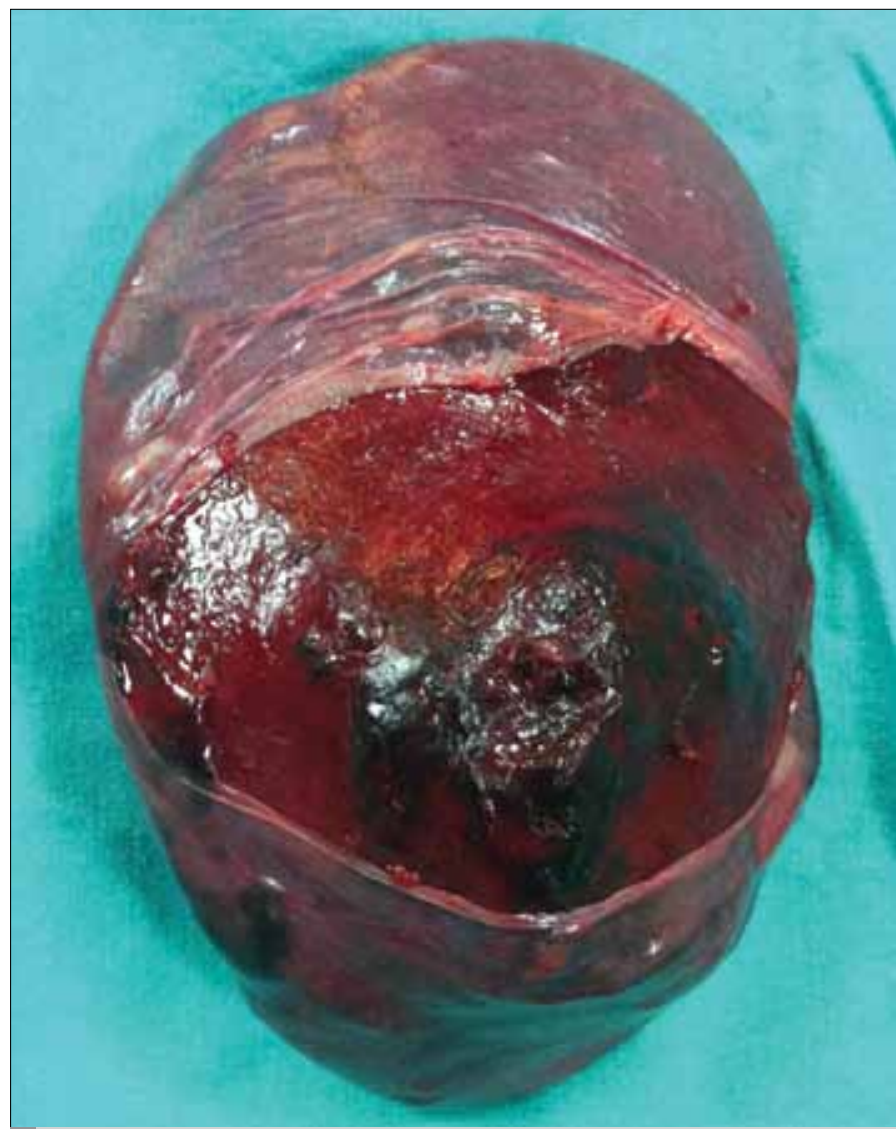

Figure 2. Spleen with image of ruptured subcapsular hematoma areas

In the study by Partihivel et al. (6), among patients who presented with blunt abdominal trauma over a period of 6 years, 8 patients were found to develop splenic rupture 48 hours or more after trauma. The medical histories of these 8 patients were remarkable for drug addiction, sickle cell anemia, cirrhosis, or HIV positivity. The medical history of our case was not remarkable for any disorder or substance 
abuse. From this perspective, the researchers consider that the lack of disorder or substance abuse in the patient's past history cannot be regarded as exclusion criteria for the development of delayed splenic rupture after sustaining blunt abdominal trauma.

In the evaluation of patients presenting to the emergency room with blunt abdominal trauma, FAST, in addition to a physical examination, biochemical tests, and direct radiographic examination, facilitates the diagnostic process. FAST involves the examination of the hepatorenal recess (Morrison's pouch), perisplenic area, and pericardiac area for the presence of free fluid and ultrasonographic examination of the liver, spleen, and kidneys. One important point that should be considered is the difficulty in detecting organ injury due to the anatomic features of the spleen and the inability to detect free fluid in the case of an unruptured subcapsular hematoma. O'Connor et al. (7) reported that sonographic hemoperitoneum could not be detected in up to $20 \%$ of splenic injuries. Consistent with this report, the current case did not exhibit free fluid in the abdomen in the initial ultrasonographic examination performed in the early period. CT is another diagnostic method that is used to evaluate patients sustaining blunt abdominal trauma. CT is superior to ultrasonography, due to the fact that it is a less operatordependent method, offering higher sensitivity for the detection of solid organ injuries. In the study by Hoskins et al. (8), which evaluated patients who sustained splenic injury, the delay in performing CT was associated with a delay in surgery and the occurrence of major postoperative complications. The same study also concluded that among patients having a higher risk for developing splenic injury, those who sustained high-energy trauma and who exhibited hemodynamic instability should be considered high-risk patients and should undergo CT as early as possible.

\section{Conclusion}

The current case report presents a patient who developed delayed splenic rupture 15 days after sustaining blunt abdominal trauma and who was treated with emergency surgical operation. Patients who develop splenic rupture in the late term may show normal physical examination findings at the initial examination. Furthermore, the possibility of developing splenic rupture should not be overlooked, even if the patient's medical history is not found to be remarkable for drug abuse, infections, or previous surgical operations. Repeated physical examinations and FAST have become more important in the management of such cases. On the other hand, CT should be requested without delay in the presence of a high-energy trauma and hemodynamic instability.

Informed Consent: Our manuscript does not include knowledge about our patient's personal information or medical data that must be kept in secret. For this reason we didn't take a written confirmation.

Peer-review: Externally peer-reviewed.

Author Contributions: Concept U.M.M., N.S.; Design - U.M.M., N.S.; Supervision - O.H., A.T.I; Materials - U.M.M., A.T.I.; Data Collection and/ or Processing - U.M.M., N.S.; Analysis and/or Interpretation - A.T.I., N.S.; Literature Review - N.S.; Writer - N.S.; Critical Review - U.M.M., O.H., A.T.I.

Conflict of Interest: The authors declared no conflict of interest.

Financial Disclosure: The authors declared that this study has received no financial support.

Hasta Onamı: Hasta onamı alınmamıştır.

Hakem değerlendirmesi: Dış bağımsız.

Yazar Katkıları: Fikir - U.M.M., N.S.; Tasarım - U.M.M., N.S.; Denetleme O.H., A.T.I.; Malzemeler - U.M.M., A.T.I.; Veri toplanması ve/veya işlemesi - U.M.M., N.S.; Analiz ve/veya yorum - A.T.I., N.S.; Literatür taraması N.S.; Yazıyı yazan - N.S.; Eleştirel İnceleme - U.M.M., O.H., A.T.I.

Çıkar Çatışması: Yazarlar çıkar çatışması bildirmemişlerdir.

Finansal Destek: Yazarlar bu çalışma için finansal destek almadıklarını beyan etmişlerdir.

\section{References}

1. SchroeppelTJ, Croce MA. Diagnosis and management of blunt abdominal solid organ injury. Curr Opin Crit Care 2007; 13: 399-404. [CrossRef]

2. Resteghini N, Nielsen J, Hoimes ML, Karam AR. Delayed splenic rupture presenting 70 days following blunt abdominal trauma. Clin Imaging 2014; 38: 73-4.[CrossRef]

3. Olthof DC, Sierink JC, van Delden OM, Luitse JS, Goslings JC. Time to intervention in patients with splenic injury in a Dutch level 1 trauma centre. Injury 2014; 45: 95-100. [CrossRef]

4. Coebergh van den Braak RR, van der Elst M, Scheffers J, Heitmann M. Splenic rupture not always painful: diagnostics after blunt abdominal trauma. Ned Tijdschr Geneeskd 2013; 157: A5295.

5. McDonald CC. Delayed splenic hematoma rupture. Am J Emerg Med 1995; 13: 540-2. [CrossRef]

6. Parithivel VS, Sajja SB, Basu A, Schein M, Gerst PH. Delayed presentation of splenic injury: still a common syndrome. Int Surg 2002; 87: 120-4.

7. O'Connor G, Ramiah V, Mclnerney J, Moughty A. Splenic rupture visualised with focused assessment with sonography for trauma (FAST): heterogeneous echogenicity of acute haemorrhage following blunt trauma. BMJ Case Rep 2012; 21: 2012.

8. Hoskins W, Jacob A, Wijeratne S, Campbell I, Taylor P. Splenic injury admitted to a rural Level 3 trauma centre: a 10-year audit. Aust J Rural Health 2013; 21: 163-9. [CrossRef] 